\title{
Peculiar anatomical traits, high durability, and potential ornamental use of Cyclanthaceae as fresh foliage
}

\author{
MARIA CAMILA MEDINA ${ }^{1,3}$, SAÚL E. HOYOS-GÓMEZ ${ }^{2}$, DIEGO DEMARCO ${ }^{1,3}$ and DINO TUBERQUIA ${ }^{1}$ \\ ${ }^{1}$ Programa de Biología, Universidad CES, Medellín, Calle 10 A No. 22-4, Antioquia, Colombia \\ ${ }^{2}$ Corporación Fragmento, Medellín, Cra 77 No 33 A 61, Antioquia, Colombia \\ ${ }^{3}$ Departamento de Botânica, Instituto de Biociências, Universidade de São \\ Paulo, Caixa Postal 11461, 05508-090 São Paulo, SP, Brazil
}

Manuscript received on February 22, 2017; accepted for publication on July 3, 2017

\begin{abstract}
Wild plant species with potential for use as ornamental green foliage are often reported. Nevertheless, there are few studies evaluating morphological and anatomical aspects associated with this use. Preliminary trials suggest that the species of Sphaeradenia (Sander ex Mast.) Harling, a Cyclantaceae that occurs from Costa Rica to Peru, is suitable to be used as fresh foliage because of attractiveness of their leaves in vase and its durability without showing tissue damage, compared with other genera of this family. Through the study of anatomical characters, it is possible to predict the potential of a species that can serve as ornamental foliage. In this study, three foliar anatomical features (thickness of the cuticle and leaf, and percentage of fibers in the mesophyll) of seven Cyclanthaceae species were evaluated, using anatomical techniques and image analysis with the LUCIA ${ }^{\circledR}$ and ImageJ softwares. Statistical analysis of the results suggests that this high durability is associated with the thickness of the cuticle and mesophyll, but not with the amount of fibers in the leaf.
\end{abstract}

Key words: anatomy, cuticle, fibers, mesophyll, Sphaeradenia laucheana.

\section{INTRODUCTION}

Currently, more than 500 species with various shapes, colors, textures and styles, mostly from tropical and subtropical environments, form the basis of the industry of foliage plants. Some of them are found in desert environments as succulent plants and cactus. They are rarely found in temperate climates. The most significant native foliage plant in temperate climates is Hedera helix,

Correspondence to: María Camila Medina

E-mail: camiliny@usp.br whose juvenile forms have been widely used (Chen et al. 2002a, b).

In general, foliage plants are resistant plants that grows in greenhouses shadows. Their leaves are quite attractive; as a result, they are used mainly as live specimens for interior decoration, rather than perishable flowers or fruits. They grow under the canopy of trees on the forest floor or live on trees as vines or epiphytes. Their tolerances to light are low, and are sensitive to high temperatures (Chen et al. 2002b, 2005, 2010). 
The basic function of the ornamental horticulture lies in the satisfying of the aesthetic needs of man. Today it is considered one of the most attractive businesses because it can provide high income per unit area. Beautifying indoor environments and indoor air purification have become key elements for the advancement of the use foliage plants, because as it has been demonstrated that they remove pollutants such as formaldehyde, benzene, toluene, xylene, and others from air (Wolverton et al. 1989, Mosaddegh et al. 2014)which are probably more polluted than outside the buildings. High levels of volatile organic compounds (VOCs. Another important factor in the steady growth of the industry foliage plants is the continuous adjunction of new plants and the development of new cultivars, which further expand the options for using of foliage plants, like houseplants (Chen et al. 2002b).

Over the years, some species belonging to several genera have been added to the list of species used in industry of foliage plants. Aglaonema, Dieffenbachia, Dracaena, Epipremnum, Ficus, Hedera, Peperomia, Philodendron, Sansevieria, Syngonium, and plants of several genera of the family Arecaceae, Polypodiaceae, Poaceae, Cyperaceae, among others, have been the backbone of the industry for at least half a century. Only the Araceae family includes at least 10 important genera of ornamentals foliage plants (Henny et al. 2008).

Worldwide production of plants and flowers has been extending over the years. Numerous production centers are localized in developing countries and they supply, on a regular basis to the principal consumers such as Japan, the United Stated and Western Europe. These countries absorb about $75 \%$ of the worldwide production of ornamentals, worth of 80.000 million euros. About 36.000 millions of euros correspond to Europe, being Germany, France and the United
Kingdom who account for about $50 \%$ of spending on ornamental (Díaz M et al. 2002, Díaz M. 2006).

Markets for foliage plants require quality standards for export. Therefore these plants must meet conditions to be used in the production of bouquets and other floral arrangements, for example, the time it can be kept in good condition after being harvested (Yuste Molina 1992, Gutiérrez et al. 2007). One of the species for export Rumohra adiantiformis, commonly known as "leather fern", that maintains its quality and freshness for a long period of time ( 25 days) after it has been harvested and packaged (López Marin et al. 2006).

On the other hand, the non-forestry use of forests is an alternative to the problem of deforestation (López Marin et al. 2006 ), particularly in regions close to urban centers (García and Polaina 2010).

Cyclanthaceae are almost exclusively confined to the Neotropical parts of the world. Nearly all the Cyclanthaceae require wet and more or less shady habitats. They are therefore mainly found in the rain forests, both in the tropical rain forests and in the montane rain forest. Just like the leaves of many Arecaceae and Araceae, the juvenile leaves of the Cyclanthaceae come very close to the ancestral leaf type of the monocotyledons. The leaf blades vary greatly in respect to their size, shape, venation, consistence and color. They are also generally more or less deeply cleft, or divided by three rather deep incision into four wedge-shaped lobes, which in their turn are regularly dentate or lobate in their upper part, or can be entire (Harling 1958, Wilder 1981). The mesophyll is sometimes distinctly differentiated into palisade and spongy parenchyma but in many species this differentiation is lacking (Wilder 1985a).

A comparative study on $S$. laucheana and six other Cyclanthaceae species with different ranges of geographical distribution, some of them already used as ornamentals foliage and landscaping, was conducted. The evaluation is to help determine the anatomical characteristics that would let explain 
its durability and potential use as foliage, thus proposing a study mechanism for prospecting new species with potential use as foliage.

Two sets of variables were taken into account; 1) durability, determined by the lifetime or duration in vase, also known as "vase life method" described by Gutiérrez et al. (2007); 2) relevant anatomical features, namely thickness of the cuticle and mesophyll thickness and the percentage of fibers present in the mesophyll and their possible impact on the vase durability.

\section{MATERIALS AND METHODS}

\section{SPECIES AND STUDY AREA}

The studied species were: Asplundia sp. Tuberquia, Asplundia flavovaginata Harling, Carludovica drudei Mast, Carludovica palmata Ruiz \& Pav, Dicranopygium calimense Harling, Sphaeradenia danielii Harling, Sphaeradenia cuatrecasana Harling and Sphaeradenia laucheana (Sander ex Mast.) Harling.

The study area is located in the Valle de Aburrá, Antioquia department. S. laucheana, $S$. cuatrecasana and $S$. danielii samples for anatomical analysis and durability tests proposed for this study were collected from a sample of relict forest in the Astilleros plantation terrain, San Antonio de Prado, Medellin. D. calimense, A. sp., A. flavovaginata, C. drudei and C. palmata samples were collected from a living collection of Cyclanthaceae in the Jardín Botánico Joaquín Antonio Uribe, Medellin.

\section{SECTIONING AND ANATOMICAL MEASUREMENTS}

An identification code was assigned to each species (Table I). The samples were preserved in $90 \%$ alcohol and taken to the Laboratory of Histology of the Universidad CES for further processing.

In order to conduct the anatomical characterization, free-hand cross-sections were made in order to compare the anatomical features supposedly related to durability in vase, namely
TABLE I

Coding of the Cyclanthaceae specimens studied.

\begin{tabular}{ccc}
\hline $\begin{array}{c}\text { Collection } \\
\text { Number }\end{array}$ & Species & $\begin{array}{c}\text { Statistical } \\
\text { Coding }\end{array}$ \\
\hline DT-3415 & Asplundia sp. & Acalle \\
DT-3413 & Asplundia flavovaginata & Aflavo \\
AC-12800 & Carludovica drudei & Cdrudei \\
AC-12801 & Carludovica palmata & Cpalma \\
AC-12800 & Dicranopygium calimense & Dcalim \\
DT-3611 & Sphaeradenia danielii & Sdaniel \\
DT-3612 & Sphaeradenia cuatrecasana & Scuatrec \\
DT-3610 & Sphaeradenia laucheana & Slauch \\
\hline
\end{tabular}

cuticle and mesophyll thickness and the number of fibers, fiber strand number and percentage of fibers in the mesophyll; of which, measurements of length and area were performed.

The sections were examined with an optical microscope Nikon Eclipse TE2000 with 100X to $400 \mathrm{X}$ magnification. Digital images, three for each leaf area were captured using a Nikon camera Digital Sight (DS-5M). Each digital image was taken from a different anatomical cut.

The measurements were made with image analysis software LUCIA ${ }^{\circledR}$ Version 5.3 (Laboratory Imaging, Prague, Czech Republic) and they were: 15 cuticle length measurements for each and 15 mesophyll thickness, measurements for each individual, and two measurements of the area occupied by the fibers in the mesophyll; this area was measured delimiting the outside of the band with a freehand line using the LUCIA ${ }^{\circledR}$ software, which yields the value of the delineated area. The number of fibers strands, number of fibers and the area occupied by the mesophyll in a visual field was registered.

\section{PLATE MOUNTING}

Given that most of the species considered in this study have leaves longer than $1 \mathrm{~m}$, the leaf was divided into three areas: apical, middle and basal, and measurements were done on cuticle, mesophyll and fibers. For each zone of the leaf, histological 
sections were performed in triplicate. The leaf cross sections were done freehand fixed with $\mathrm{CaCl} 2$ 16\% (Keating 2014) and stained with Cresyl Violet Acetate (CVA). The blades were mounted semipermanent.

\section{DURABILITY TEST}

The durability test was based on the proposed criteria by Gutiérrez et al. (2007): a specimen is reputed to have good performance of vase life if the material retains its initial characteristics after 15 days of evaluation period; i.e. there is no collapse of stem, dehydration, damage by fungi, discoloration, geotropism or necrosis. For this test, two leafs, including $0.15 \mathrm{~m}$ of petiole, from different individuals of each species, were placed in containers with water and subjected to daily monitoring; the external appearance of the leaf was recorded in photographs every 10 days (Fig. 1). Considering that for ornamental foliage can be used, it must have duration of two weeks, the durability test conducted for 5 weeks for detailed observation of each species.

\section{DURABILITY TEST VERSUS CUTICLE AND MESOPHYLL THICKNESS, AND PERCENTAGE OF MESOPHYLL FIBERS}

Three anatomical variables were selected would be related to high durability in vase of each species (cuticle and mesophyll thickness, and mesophyll percentage of fibers). To establish this association, the samples used for anatomical measurements and durability tests were obtained from the same individual. The leaf blade was divided into three sections: apical, middle and basal, for performing measurements of anatomical variables. With the average values of the measurements were performed by lineal regression between the results of durability results and anatomical measurements.

The percentage of each cut fibers was obtained by adding the area measurements strands fibers present in the mesophyll of each cross-section, this value is multiplied by one hundred and divided by the mesophyll total area of same cross section. Additionally it was done counting the number of fibers and the number of strands for each crosssection fibers

\section{STATISTICAL ANALYSIS}

The thickness of the cuticle (cut), mesophyll thickness (mes) and percentage of fibers (pfiber), between species and between areas of the leaf blade were processed using the free software (" $R$ development Core Team" 2011).

Each variable was analyzed using a two way ANOVA including species factor and the area factor of the sheet. The model includes the interaction between the two factors. The Bonferroni adjustment was used for multiple comparisons between pairs of species. The ANOVA model assumptions are validated by the residual graph technique. The cuticle (cut) and mesophyll (mes) values were transformed to natural logarithm in order to correct for heterogeneity of variances. The resulting averages for these variables (cut and mes) were transformed back to its original scale.

\section{RESULTS}

\section{DURABILITY TEST}

Two leaves from different individuals of the same species were subjected to the test. The eight species tested showed different lengths of durability in vase, as illustrated in Fig. 1. The test time takes into account that Sphaeradenia laucheana lasts about three months without any harm, while other species last a shorter time. It was apparent that both leaves, of the same species, showed signs of deterioration simultaneously, during one-day interval, except C. palmata whose leaves deteriorated seven days apart (18 vs. 25 days). The main cause of removing species was necrosis in the apical area of the leaves; dehydration and leaf crinkling eliminated only $S$. cuatrecasana. 
a.

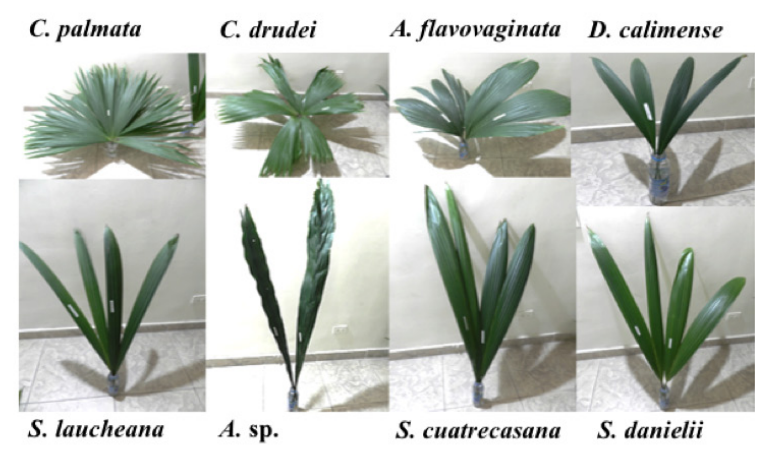

b.

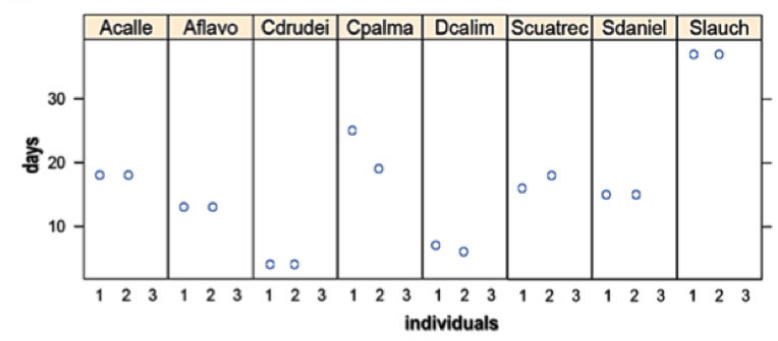

Figure 1 - Durability test (vase life) of eight species of Cyclanthaceae during 37 days. a. State of the leaves on the $16^{\text {th }}$ day of monitoring. b. Duration times for each species.

\section{CUTICLE MEASUREMENTS}

No significant differences in the thickness of the cuticle in relation to the three areas of the leaf within the same species; nevertheless there are differences in the thickness of the cuticle $(\mathrm{P}<0.0001)$ between the eight species as shown in Table II.

D. calimense presented the lowest values of cuticle thickness. The species belonging to the genus Sphaeradenia showed the highest values in the cuticle thickness measurements and $S$. laucheana showed the highest values for the three areas of the leaf (Table II).

\section{DURABILITY TEST AND THICKNESS \\ MEASUREMENTS CUTICLE}

Long durability (more than 15 days of vase life), as shown by linear regressions (Fig. 2), may be associated with a thicker cuticle in some species (S. cuatrecasana, S. danielii and S. laucheana,)
(Figs. 5, 6, 7), being more evident for the species $S$. laucheana, which lasted 37 days and presented the highest values of cuticle thickness.

\section{MESOPHYLL THICKNESS MEASUREMENTS}

A marked difference in the thickness of the mesophyll is observed among the analyzed species $(\mathrm{P}<0.0001)$. S. danielii and S. laucheana were the species that showed thicker mesophylls and $C$. drudei showed the lowest thickness of the mesophyll (Table II) values.

Mesophyll thicknesses between different areas of the leaf (apical, middle and basal) of all individuals from the eight species studied were compared. A significant difference in mesophyll thickness between different areas of the leaf, with values ranging between 200 and 600 micrometers in $S$. danielii and S. laucheana was observed, the basal area being thicker in both species.

\section{DURABILITY TEST VS. MESOPHYLL THICKNESS MEASUREMENTS}

There is an apparent association between the mean values of mesophyll thickness and durability in vase (Fig. 3). The mesophyll of A. sp., S. cuatrecasana and $S$. laucheana showed similar ratios with respect to the thickness of the mesophyll, but S. laucheana durability surpassed the other species.

\section{PERCENTAGE OF FIBERS}

The values of fiber percentage from the eight species vary significantly $(\mathrm{P}=0.0012)$. The species with the higher percentage of fibers was $C$. palmata, with the highest value for the apical area and the lowest for the basal area. (Apical: 8.18\%, Central: 7.35\%, basal: $6.41 \%$ ). This species had the highest number of fibers in the central region (38.75 fibers), and the largest number of bands for the three areas of the sheet (apical: 13.00, central: 17.25, basal: 13.25).

Sphaeradenia laucheana had the highest number of fibers in the apical and basal region of 
TABLE II

Mean values (micrometers) of measurements of thickness of the cuticle, mesophyll thickness, percentage and number of fibers in the mesophyll with their respective standard deviations.

\begin{tabular}{|c|c|c|c|c|c|c|c|}
\hline & Species & Apical & ED & Middle & ED & Basal & ED \\
\hline \multirow{8}{*}{ Cuticle } & A. sp. & 3.59 & 1.10 & 3.89 & 1.08 & 3.87 & 1.08 \\
\hline & A. flavovaginata & 2.96 & 1.08 & 2.90 & 1.08 & 3.12 & 1.08 \\
\hline & C. drudei & 4.43 & 1.10 & 4.02 & 1.08 & 4.22 & 1.08 \\
\hline & C. palmata & 4.12 & 1.10 & 4.74 & 1.10 & 4.84 & 1.10 \\
\hline & D. calimense & 1.87 & 1.08 & 2.17 & 1.08 & 3.22 & 1.08 \\
\hline & S. cuatrecasana & 5.44 & 1.08 & 8.09 & 1.10 & 6.09 & 1.08 \\
\hline & S. danielii & 5.24 & 1.08 & 6.46 & 1.08 & 8.02 & 1.08 \\
\hline & S. laucheana & 9.95 & 1.08 & 11.46 & 1.08 & 12.70 & 1.08 \\
\hline \multirow{8}{*}{ Mesophyll } & A. sp. & 244.52 & 1.05 & 315.54 & 1.05 & 428.65 & 1.05 \\
\hline & A. flavovaginata & 191.35 & 1.05 & 246.92 & 1.05 & 335.44 & 1.05 \\
\hline & C. drudei & 138.77 & 1.05 & 179.07 & 1.05 & 243.27 & 1.05 \\
\hline & C. palmata & 145.73 & 1.05 & 188.06 & 1.06 & 255.48 & 1.06 \\
\hline & D. calimense & 160.00 & 1.05 & 206.74 & 1.05 & 280.49 & 1.05 \\
\hline & S. cuatrecasana & 198.25 & 1.05 & 255.83 & 1.05 & 347.54 & 1.05 \\
\hline & S. danielii & 256.28 & 1.05 & 330.72 & 1.05 & 449.27 & 1.05 \\
\hline & S. laucheana & 261.61 & 1.05 & 337.59 & 1.05 & 458.61 & 1.05 \\
\hline \multirow{8}{*}{ Fiber Percentage } & A. sp. & 1.96 & 0.95 & 2.84 & 0.95 & 2.57 & 0.95 \\
\hline & A. flavovaginata & 3.76 & 0.95 & 4.64 & 0.95 & 5.63 & 0.95 \\
\hline & C. drudei & 4.36 & 0.95 & 5.45 & 0.95 & 4.91 & 0.95 \\
\hline & C. palmata & 8.18 & 0.95 & 7.35 & 0.95 & 6.41 & 0.95 \\
\hline & D. calimense & 3.82 & 0.95 & 3.30 & 0.95 & 4.16 & 0.95 \\
\hline & S. cuatrecasana & 5.78 & 0.95 & 4.95 & 0.95 & 6.66 & 0.95 \\
\hline & S. danielii & 2.16 & 0.95 & 2.41 & 0.95 & 7.41 & 0.95 \\
\hline & S. laucheana & 6.55 & 0.95 & 4.75 & 0.95 & 4.74 & 0.95 \\
\hline \multirow{7}{*}{ Number of fibers } & A. sp. & 8.25 & 4.92 & 11.25 & 4.92 & 11.50 & 4.92 \\
\hline & A. flavovaginata & 16.50 & 4.92 & 35.00 & 4.92 & 51.25 & 4.92 \\
\hline & C. drudei & 18.00 & 4.92 & 29.50 & 4.92 & 33.25 & 4.92 \\
\hline & C. palmata & 35.00 & 4.92 & 38.75 & 4.92 & 35.50 & 4.92 \\
\hline & D. calimense & 13.50 & 4.92 & 12.08 & 4.92 & 18.75 & 4.92 \\
\hline & S. danielii & 17.00 & 4.92 & 20.50 & 4.92 & 63.00 & 4.92 \\
\hline & S. laucheana & 47.50 & 4.92 & 34.25 & 4.92 & 65.25 & 4.92 \\
\hline
\end{tabular}


TABLE II (continuation)

\begin{tabular}{cccccccc}
\hline & Species & Apical & ED & Middle & ED & Basal & ED \\
\hline & A. sp. & 5.00 & 1.43 & 5.25 & 1.43 & 4.50 & 1.43 \\
& A. flavovaginata & 6.50 & 1.43 & 8.50 & 1.43 & 11.00 & 1.43 \\
Number of bands & C. drudei & 6.50 & 1.43 & 14.50 & 1.43 & 14.00 & 1.43 \\
& C. palmata & 13.00 & 1.43 & 17.25 & 1.43 & 13.25 & 1.43 \\
& D. calimense & 4.75 & 1.43 & 4.00 & 1.43 & 5.50 & 1.43 \\
& S. danielii & 4.00 & 1.43 & 6.00 & 1.43 & 12.50 & 1.43 \\
& S. laucheana & 5.00 & 1.43 & 4.50 & 1.43 & 9.50 & 1.43 \\
\hline
\end{tabular}
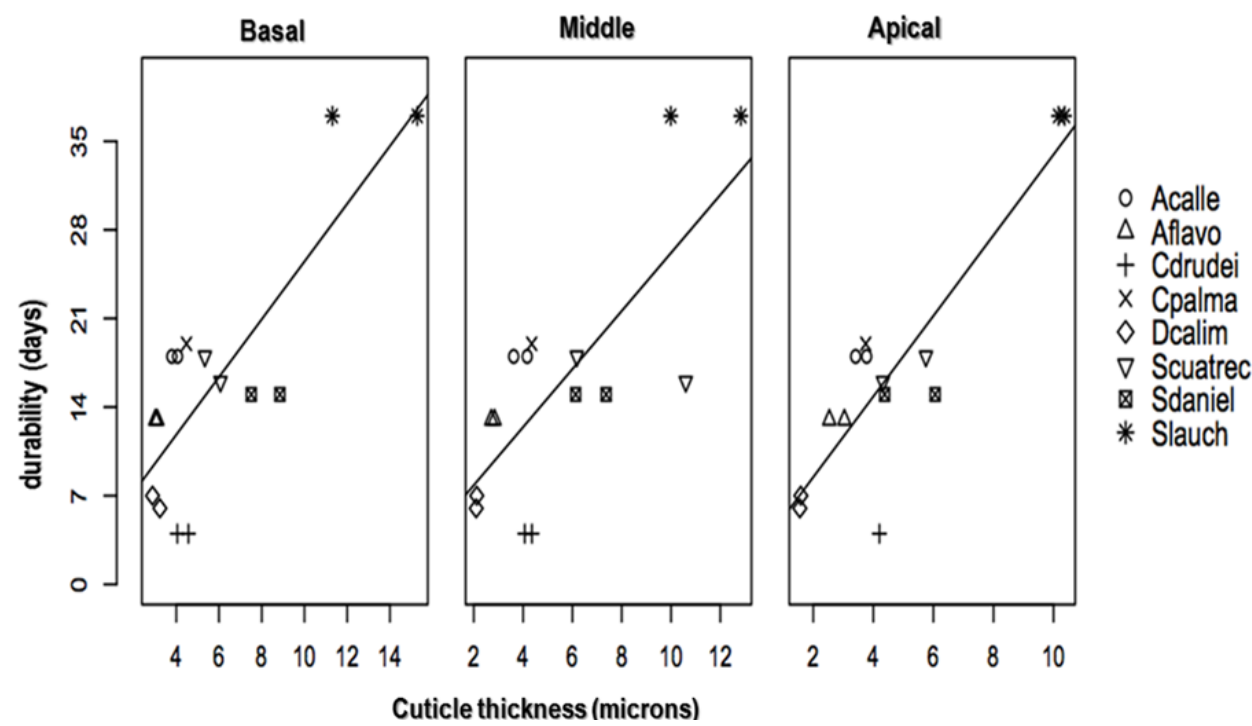

Figure 2 - Relationship between the mean values of cuticle thickness and durability in vase for eight species of Cyclanthaceae. See name species in Table I.

the leaf (apical: 47.50, basal: 65.25), outnumbering C. palmata (apical: 35.00, basal: 35.50). It should be realized that the bands of fibers vary in sizes and shapes, depending on the morphology of the fibers comprising it. In $S$. laucheana, few bands with numerous fibers of small size and smaller lumens are observed (Fig. 7). In C. palmata, numerous bands with few large fibers and large lumens are observed (Fig. 9), and also present a higher percentage of fibers and number of bands, and $S$. laucheana a larger number of fibers.

The percentage and organization of the fibers did not present a uniform distribution in the mesophyll, since these characteristics varied according to each species. This is clearly observed in the two studied species of the genus Carludovica, having a shape, amount and distribution of fibers obviously different (Figs. 9, 10). Some species have the highest percentage of fibers in the apical region (C. palmata and S. laucheana), other ones in the central region ( $A$. sp. and $C$. drudei), and other ones in the basal region ( $S$. cuatrecasana, S. danielii, A. flavovaginata and D. calimense) as per Table II. On the other hand, some species have scarce fibers bands in mesophyll (Fig. 8).

\section{DURABILITY TEST VS. PERCENTAGE OF FIBERS}

There is not a high correlation between the durability test and the percentage of fibers, as shown in Figure 4. Some species have a higher percentage of fibers in the apical area decreasing towards the basal zone and in other ones the opposite case occurs. 

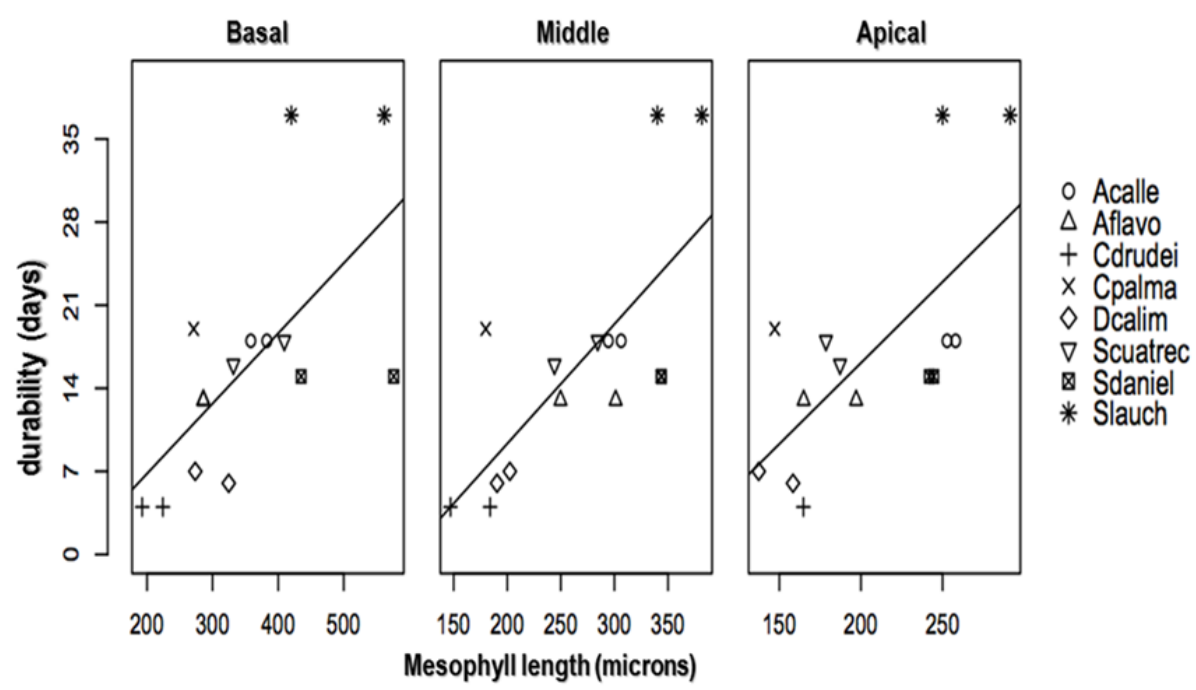

Figure 3 - Relationship between the mean values of mesophyll thickness and durability in vase for eight species of Cyclanthaceae. See names of each species in Table I.
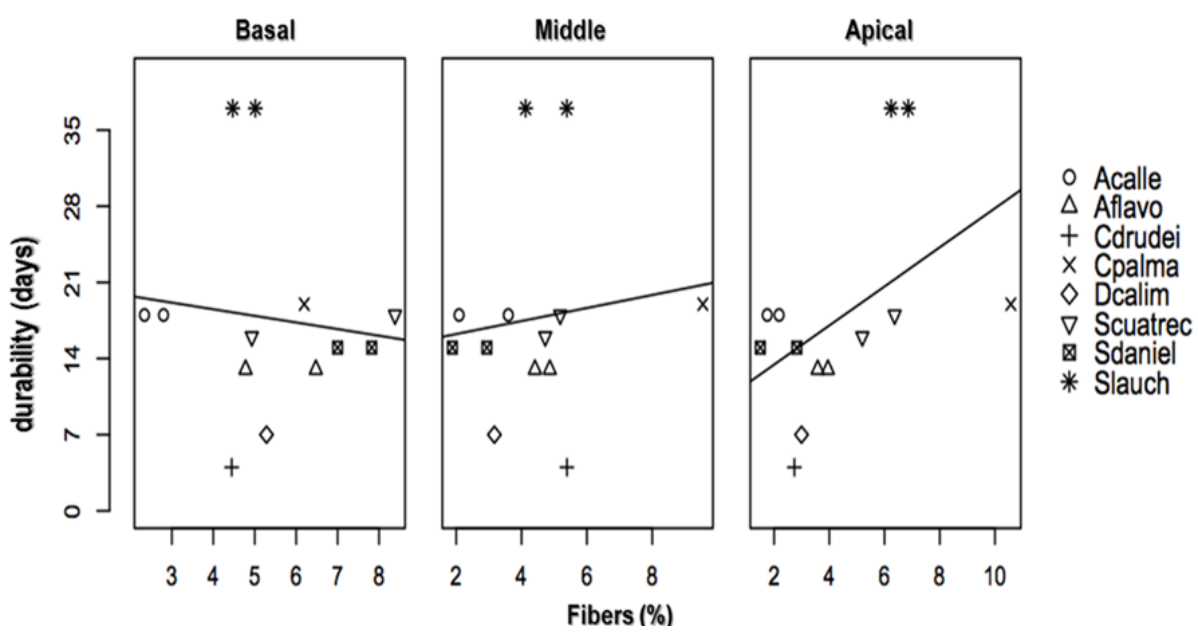

Figure 4 - Mean values of the percentage of fiber compared with durability in vase for eight species of Cyclanthaceae. See species names in Table I.

Carludovica palmata presents the highest percentage of fibers in the mesophyll in the basal and central areas of the leaf, reaching a 20-day average durability, but $A$. sp. and $S$. cuatrecasana present the same durability; this later one with the lowest percentage of fibers, and $S$. laucheana presents a medium percentage of fibers, and the longest durability.

\section{DISCUSSION}

Sphaeradenia laucheana is a species with potential for use as ornamental foliage (Gutiérrez et al. 2007) because of its high durability in vase. The results of this study suggest that high durability is associated with the thickness of the cuticle and mesophyll compared to other species of the Cyclanthaceae family and to a lesser extent this durability is associated with the percentage of sclerenchyma fibers.

In Cyclanthaceae family, a combination of layers appears in the cuticle, which causes it to observe much thicker (Wilder 1985a). This combination occurs as two discrete regions or fields: the first, called no cutinized region and the 
second the cutinized region, both covered by a cuticle sensu stricto. The cuticle can be thicker in the abaxial or adaxial region or may be equal in both epidermises. The combined thickness of these layers varies depending on the species. Harling (1958) reports that the leaves in the species of the group he called informally Sphaeradenia (with three genera) are more coriaceous than those of the group called Asplundia (six genera). Anatomical studies by Wilder (1985a) show that some species of the genera Dicranopygium and Asplundia have the lowest thickness of cuticle and most species of the genus Sphaeradenia present the largest thickness. These results agree with those obtained in this study, where three species of the genus Sphaeradenia showed the highest values of cuticle thickness as shown in Table II.

It is known that most of species of Sphaeradenia, grow above $2000 \mathrm{~m}$ altitude, and S. laucheana reaches extreme altitudinal limits, even up to 3700 m altitude (Eriksson 1995). Thick cuticles in some plants could be related to ecological requirements in high mountain environments (Hlwatika and Bhat 2002).

Some species of Cyclanthaceae, especially Sphaeradenia laucheana, show features that allow them to be resistant to desiccation, which enhance the possibility of being used as ornamentals. Their features include specialized cells as fibers, cells containing crystals (this occur solely in the mesophyll) (Wilder 1985b), tanniniferous and internal secretory tissues as mucilage canals or cavities are found in all the species of family taking place in the stem, petiole, the peduncle, inflorescence, often also in the root and in the costa of the leaf blade (Harling 1958). According to (Fahn and Cutler 1992) the mucilage in plants is suggested to serve for water retention, because of their great ability to imbibe water, it was assumed that the mucilage plays a role in regulation of the water economy in plants. It has been suggested that the presence of fibers may have a role in storing water. This allows them to have greater desiccation tolerance. Wilder (1985c) says that in all species the mesophyll contains strands of one or more fibers, which normally are parallel to the longitudinal veins.

In all species studied, the fibers appear organized in strands, scattered throughout all regions of the mesophyll (adaxial, central and abaxial). Fiber strands occur in larger quantity in the adaxial region in $S$. cuatrecasana and, $S$. danielii. The fiber strands occur in similar amounts in both regions of mesophyll in $D$. calimense, $A$. sp., and A. flavovaginata, in the apical area of the leaf. Fiber strands were observed scattered throughout the mesophyll in C. drudei and C. palmata as they were observed by Wilder (1985c), who reported the fiber strands concentrated mainly in the abaxial region of the leaf blade, in some species of this family.

It should be considered that the sclerenchyma cell morphology varies in shape and size according to the species (Wilder 1985c). In some species the fibers had wide lumens that occupy a large area of the cell, and thus occupying large areas in the mesophyll (C. palmata, A. sp. and D. calimense). Therefore, when measuring areas occupied by fibers in these three species area, large areas were obtained. Fibers with medium size lumens and generally small for these two species were observed in A. flavovaginata, C. drudei and S. laucheana. The strands of these fibers also have medium sizes, from 2 to 8 fibers per strand. In other cases, as occur in species of the genus Sphaeradenia; fibers presented lumens of small sizes, but with more lignified area. Wilder (1985c) reported that depending on the species, mesophyll fibers might generally have narrow or broad lumens. In some species, some fibers of larger veins are broader and exhibit wider lumens than those of the mesophyll. These fibers were grouped in large strands, up to 20 fibers per band; these strands occur in small quantities in the mesophyll; when the areas occupied by the fibers in 

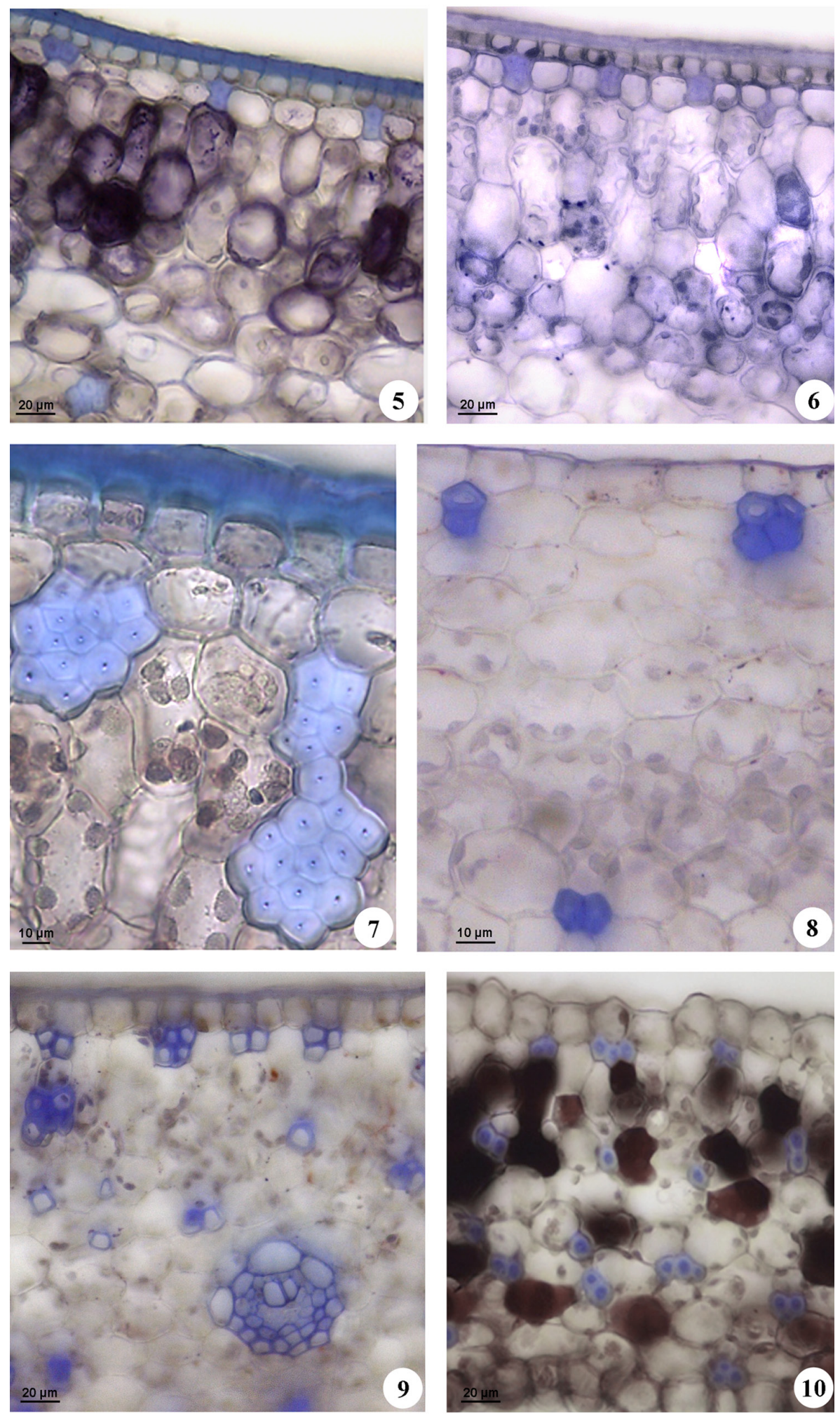

Figures 5-10 - Cross-sections of leaves of Cyclanthaceae. 5. S. cuatrecasana cuticle 100x. 6. S. danielli cuticle 100x 7. S. laucheana fiber strands and cuticle 40x.100x 8. A. Alavovaginata fibers strands 9. C. palmata fiber strands 40x. 10. C. drudeii fiber strands 40x. 
the mesophyll are compared between species, those of the genus Sphaeradenia, show the lowest ones.

The percentage of fibers present in the mesophyll is not, apparently, a determining factor in the high or low vase durability. C. palmata presents the highest value in percentage of fibers but a medium vase life; $S$. laucheana presents a medium fiber percentage but the maximum vase life. $A$. sp. presents the minimum fiber percentage but its vase life is comparable with that of $C$. palmata. These observations highlight the importance of measurements to be performed accompanied by close observation of the organization and morphology of the fibers in the mesophyll.

This study does not support the conclusion that the durability is directly related to any of the anatomical attributes evaluated in particular. It may suggest that the high vase durability of Sphaeradenia laucheana has to do with an interaction of different variables; cuticle thickness, mesophyll thickness and percentage of fibers present in the mesophyll. Some species included in this study, grow in low-middle elevations $(C$. palmata, A. sp., A. flavovaginata); others grow in high altitudes (three species of Sphaeradenia, up to 3200 high). These factors could be associated with the anatomical characteristics and their variations, depending on the species and the place where it grows, so that these anatomical attributes that have to do with the ability to adaptation and survival of the plant and to its ability for a long vase life (Tuberquia 2007).

This study provides elements to suggest that the evaluation of different anatomical features of a plant may be useful in the selection of species with potential for use as ornamental foliage. This is just an approximation to an almost unexplored field of research with large possibilities in the generation of useful knowledge on sustainable use of plant resources.

\section{ACKNOWLEDGMENTS}

We want to express our appreciation to the Botanical Garden Joaquín Antonio Uribe (Medellín) for the access granted to live specimens; Universidad CES for the logistical support; Yeison Montoya for his help in the field; the Biological Engineering Magda Ledesma Eraso, for advice in managing LUCIA ${ }^{\circledR}$ Software, and Biologist Pablo Andres Guzmán for advice on statistical analysis.

\section{REFERENCES}

CHEN J ET AL. 2002a. Production and Interior Performances of Tropical Ornamental Foliage Plants Grown in Container Substrates Amended with Composts. Compost Sci Util 10: 217-225.

CHEN J ET AL. 2002b. Development of New Foliage Plant Cultivars. Trends in new crops and new uses, p. 466-472.

CHEN J ET AL. 2005. Response of Tropical Foliage Plants to Interior Low Light Conditions. Acta Hort, p. 51-56.

CHEN J ET AL. 2010. The Foliage Plant Industry.

DÍAZ MJA. 2006. Diagnóstico de la cadena productiva de heliconias y follajes en los departamentos del eje cafetero y Valle del Cauca ( Colombia ) Consultor BiocomercioBTFP, p. 1-46.

DÍAZ MJA ET AL. 2002. Sondeo del mercado internacional de Heliconias y Follajes Tropicales.

ERIKSSON R. 1995. The genus Sphaeradenia (Cyclanthaceae). Opera Bot 126: 1-106.

FAHN A AND CUTLER DF. 1992. Xerophytes. Encyclopedia of plant taxonomy. Braun H, Carlquist S, Ozenda P and Roth I (Eds), Gebrüder Borntraeger.

GARCÍA C AND POLAINA J. 2010. Marco conceptual para productos no maderables del bosque en manglares de Colombia. Gest Ambien 10: 169-178.

GUTIÉRREZ IC ET AL. 2007. Prospercción y evaluación de especies con potencial de follaje para la elaboración de bouquets. Agron Colom 25: 176-188.

HARLING GW. 1958. Monograph of the Cyclanthaceae. Acta Horti Berg 18: 1-428.

HENNY RJ ET AL. 2008. Tropical Foliage Plant Development: Breeding Techniques for Anthurium and Spathiphyllum. Series of Environmental Horticulture Department, p. 1-4.

HLWATIKA CN AND BHAT R. 2002. An Ecological Interpretation of the Difference in Leaf Anatomy and its Plasticity in Contrasting Tree Species in Orange Kloof, Table Mountain, South Africa. Ann Bot 89: 109-114.

KEATING RC. 2014. Preparing plant organs for Light Microscopic study: A compendium of simple techniques. Missouri Botanical Garden Press. 
LÓPEZ MARIN J ET AL. 2006. Complementos ornamentales de verde y flor.

MOSADDEGH MH ET AL. 2014. Phytoremediation of benzene, toluene, ethylbenzene and xylene contaminated air by $D$. deremensis and $O$. microdasys plants. J Environ Heal Sci Eng 12: 39.

R DEVELOPMENT CORE TEAM. 2011. R: A lenguage and enviroment for statistical computing. R for Statistical Computing, Vienna, Austria. ISBN 3-900051-07-0, URL http://www.R-project.org/.

TUBERQUIA D. 2007. Caracterización taxonómica, ecológica y etnobotánica de las especies de la familia Cyclanthaceae en la jurisdicción de CORANTIOQUIA 70.

WILDER GJ. 1981. Morphology of Adult Leaves in the Cyclanthaceae ( Monocotyledoneae). Bot Gaz 142: 564588.
WILDER GJ. 1985a. Anatomy of Noncostal Portions of Lamina in the Cyclanthaceae (Monocotyledoneae). I. Epidermis. Bot Gaz 146: 82-105.

WILDER GJ. 1985b. Anatomy of Noncostal Portions of Lamina in the Cyclanthaceae (Monocotyledoneae). III. Crystal Sacs, Periderm, And Boundary Layers Of The Mesophyll. Bot Gaz 146: 375-394.

WILDER GJ. 1985c. Anatomy of Noncostal Portions of Lamina in the Cyclanthaceae (Monocotyledoneae). II. Regions of Mesophyll, Monomorphic and Dimorphic Ordinary Parenchyma Cells, Mesophyll Fibers, and Parenchyma-Like Dead Cells. Bot Gaz 146: 213-231.

WOLVERTON B ET AL. 1989. Interior landscape plants for indoor air pollution abatement. National Aeronautics and Space Addminitration, NASA, p. 1-5.

YUSTE MOLINA F. 1992. Verdes ornamentales para floristeria. 